\title{
Molecular mapping of Factor XIIIa-enriched dendrocytes in the skin (Review)
}

\author{
PASCALE QUATRESOOZ, PHILIPPE PAQUET, TRINH HERMANNS-LÊ and GÉRALD E. PIÉRARD
}

Department of Dermatopathology, University Hospital of Liège, Liège, Belgium

Received May 12, 2008; Accepted June 23, 2008

DOI: 10.3892/ijmm_00000036

\begin{abstract}
The human dermis contains a series of dendritic cells which express different phenotypes including Factor XIIIa immunoreactivity. This compound is related to a blood coagulation factor participating in angiogenesis, in the final stages of the clotting cascade and in wound healing. In normal skin, Factor XIIIa is expressed in specific dermal dendrocytes (DD) derived from the monocyte/macrophage lineage or from a mesenchymal origin. DD are located predominantly around the microvasculature in the adventitial dermis, at the dermo-epidermal junction, and around skin appendages, but normally not within the epidermis. Increased numbers of Factor XIIIa+ DD are present in a host of specific cutaneous inflammatory and fibrotic conditions. In tumor pathology, immunophenotypic differences are found between dermatofibromas and other fibrohistiocytic entities, most notably dermatofibrosarcoma protuberans. In addition, Factor $\mathrm{XIIIa}^{+}$DD are likely to be involved in the progression and regression of some malignancies including cutaneous melanoma and basal cell carcinoma.
\end{abstract}

\section{Contents}

1. Introduction

2. Factor XIIIa ${ }^{+}$cells

3. Factor XIIIa ${ }^{+}$dendrocytes during fetal life

4. Factor XIIIa ${ }^{+}$dendrocyte immuno-phagocytic function

5. Factor XIIIa ${ }^{+}$dendrocyte tensegrity

6. Factor XIIIa ${ }^{+}$dendrocytes in dermatitides

7. Factor XIIIa ${ }^{+}$dendrocytes in phagocytic disorders

8. Factor XIIIa ${ }^{+}$dendrocytes in fibroplasias

9. Factor XIIIa ${ }^{+}$dendrocytes in wound healing

10. Factor XIIIa+ dendrocytes in neoplasms

11. Conclusion

Correspondence to: Professor G.E. Piérard, Department of Dermatopathology, CHU Sart Tilman, B-4000 Liège, Belgium

E-mail: gerald.pierard@ulg.ac.be

Key words: Factor XIIIa, dermal dendrocyte, dendritic cell, malignant melanoma, graft-versus-host reaction, toxic epidermal necrolysis

\section{Introduction}

The dermis contains dendritic cells interacting with the microvasculature $(1,2)$. Dermal dendrocytes (DD) exhibit some degree of immunophenotypic and functional heterogeneity $(3,4)$. Morphologically, they may be confused with other cells such as fibroblasts and mast cells. In the skin, DD can be distinguished by 3 main immunohistochemical markers: the enzyme Factor XIIIa, CD34 antigen and thrombomodulin $(5,6)$.

Factor XIII is a blood coagulation proto-transglutaminase (7), which becomes an activated component during the final stages of the clotting cascade as a result of the interaction with thrombin and $\mathrm{Ca}^{2+}$. Factor XIII plays a key role in fibrin stabilisation. The plasma enzyme is a heterotetramer composed of paired A and B sub-units (A2B2). In contrast, in the cellular form, Factor XIIIa is a homodimer of A sub-units (A2) lacking the $\mathrm{B}$ sub-units. The gene coding for the A and B sub-units are mapped on the chromosomes 6p24-25 and 1a31-32.1, respectively. Cells of bone marrow origin are believed to be the main source of the sub-unit A in plasma Factor XIII. Hepatocytes are also involved in the same process. The subunit B of plasma Factor XIII is synthesized in the liver.

In addition to the functional homeostatic role in clot formation, Factor XIII is significant in wound healing (8) and embryo implantation (9), which involve angiogenic pathways (10). In wound healing, Factor XIII is believed to be central to reducing vascular endothelial permeability.

\section{Factor XIIIa ${ }^{+}$cells}

Immunohistochemical identification of Factor XIIIa in tissue sections has been available for $\sim 20$ years $(1,11,12)$. Factor $\mathrm{XIIIa}^{+}$cells were presented in various organs including skin, esophagus, stomach, small and large bowels, bladder, lungs and kidneys. Lower quantities of Factor XIIIa ${ }^{+}$cells are found in the liver, thyroid, testis and spleen (13). Factor XIIIa is also expressed in human megakaryocytes, platelets, peripheral blood monocytes, peritoneal-alveolar-brain macrophages, follicular dendritic reticulum cells of reactive lymphoid follicles, tumor-associated macrophages, encapsulated lymphoid structures, lymph nodes of Hodgkin disease, primary and metastatic brain tumors, as well as in the placenta, uterus and prostate (13). The elevated numbers of Factor XIIIa ${ }^{+}$cells in such tissues suggest they have an important role in immune responses. 
In the skin, Factor XIIIa ${ }^{+}$DD are normally confined to the dermis, with greater quantities present within the papillary dermis, at the dermo-epidermal junction, and in loose areolar connective tissue around the appendages, particularly the pilosebaceous units and abutted to vessels $(1,12-14)$. High numbers of these cells are present in the septa between fat lobules. In contrast, they are scattered within the reticular dermis.

The antigenic epitope of Factor XIIIa is localised predominantly in the cytoplasm of the specific DD, with some membraneous labeling (14). Factor XIIIa ${ }^{+}$DD exhibit structural aspects depending on their location in the dermis. At the dermo-epidermal junction, they appear as moderately larger demarcated DD, with prominent cell bodies and tapering cell processes (15), most of which are orientated towards the epidermis. Conversely, Factor XIIIa ${ }^{+}$DD located deeper in the dermis are narrow and the dendritic processes less prominent. The ultrastructural features of DD encompass rows of pinocytic vesicles beneath the plasma membrane, small dense fibronexus-like plasma membrane plaques, gap junctions and some phagolysosomes (15-20).

In vitro, $\mathrm{DD}$ are considered to be established by a culture of peripheral blood monocytes in the presence of granulocyte macrophage-colony stimulating factor (GMCSF) and interleukin-4. The colocalization of $\alpha 1$ (XVI) collagen and Factor XIIIa inside DD, and their coordinate induction in $\mathrm{CD} 14^{+}$monocyte-derived dendritic cells in vitro is physiologically important (21). It appears that $\alpha 1$ (XVI) collagen is constitutively expressed by most DD and dendritic cells differentiated from peripheral blood monocytes in vitro. Type XVI collagen expressed in Factor XIIIa+ DD probably forms intermolecular cross-linking through the NC11 domain. The reaction catalyzed by Factor XIIIa contributes to the structural integrity and tensegrity of Factor $\mathrm{XIIIa}^{+}$dendritic cell-rich tissues.

\section{Factor XIIIa ${ }^{+}$dendrocytes during fetal life}

In the fetus, Factor XIIIa ${ }^{+}$cells are most abundant in the dermis and other connective tissues $(22,23)$. Numerous large, stellate cells in placental villi, deciduas, and chorionic membranes express Factor XIIIa at 7-9 weeks of the gestational age, before the onset of fetal hematopoiesis (23). Factor XIIIa immunolabeling appears heterogeneous in the early and late fetal tissues, in rounded and dendritic cells. Some cells express Factor XIIIa and certain monocyte markers. They are identified in close association with blood vessels and lymphoid organs in the late fetus and in the placental villi at the end of gestation. Other rounded and dendritic cells express Factor XIIIa but not monocyte markers. They are found in fetal connective tissues at all gestational ages as well as after birth. These observations suggest that two Factor XIIIa ${ }^{+}$cell populations co-exist (23). One DD population present at all developmental ages does not express monocyte markers, and probably differentiates in situ from the primitive mesenchyme. The other DD population appears mainly after the initiation of fetal hematopoiesis, co-expressing some monocyte markers, showing HLA-DR positivity and being capable of antigen presentation.

\section{Factor XIIIa ${ }^{+}$dendrocyte immuno-phagocytic function}

DD appear heterogeneous according to their immunophenotype, stage of maturation and function $(24,25)$. Cells of the skin exhibit varied presentations which are influenced by local tissue microenvironmental conditions $(26,27)$. Thus, DD may represent peculiar types of mesenchymal cells that are sufficiently plastic to express different phenotypic markers at specific stages of the differentiation and/or proliferation cycle, and to alter their morphology based on the extracellular matrix and neighbouring cells $(28,29)$.

$\mathrm{DD}$ of bone marrow origin are $\mathrm{CD}^{4} 5^{+}(28)$. They exhibit particular histoenzymatic and immunohistochemical features sharing similarities with antigen-presenting cells (HLA-DR+, $\mathrm{LFA}^{+}$and HLA-DQ ${ }^{+}$(30). They are quite distinct from fibroblasts $(3,11,13,14)$. Approximately $80 \%$ of DD are positive for myelomonocytic markers CD13 and CD33, but there is no CD15 immunoreactivity. Unlike Langerhans cells they do not express CD1a and are phagocytic $(11,31,32)$. Some sub-populations share common phenotypic features with monocytes and macrophages $\left(\mathrm{CD} 11 \mathrm{~b}^{+}, \mathrm{CD} 11 \mathrm{c}, \mathrm{CD} 14^{+}\right.$, $\mathrm{CD}_{2} 2^{+}$and $\left.\mathrm{CD} 6^{+}\right)$. Expression of the surface Fc and complement receptors is critical for phagocytosis since they are involved in particle binding and uptake. DD do not express Fc $\gamma$ RII which enhances phagocytosis of opsonized particles. Furthermore, the majority of DD express the complement receptors type III and IV, which are involved in the uptake of $\mathrm{C} 3 \mathrm{~b}$ - or iC3b-coated microorganisms.

Factor XIIIa expression is a marker for alternative macrophage activation, while the absence of Factor XIIIa in monocyte-derived macrophages is an indicator of their inactivated state (33).

\section{Factor XIIIa ${ }^{+}$dendrocyte tensegrity}

The intracellular role of Factor XIIIa remains comparatively unexamined. This molecule belongs to the transglutaminase family. The activation mechanism for this intracellular form of Factor XIIIa is unknown, but Factor XIIIa has been suggested to undergo conformational changes induced by the ionic environment rather than by proteolysis. Such an activation mechanism is effective at high ionic strength. When the intracellular $\mathrm{Ca}^{2+}$ concentration becomes elevated, the slow progressive non-proteolytic activation of Factor XIIIa occurs. Thus, the native zymogen is transformed into the active transglutaminase. In some circumstances, a low $\mathrm{Ca}^{2+}$ concentration in the physiological range of plasma is sufficient to support the process. Different cytoskeletal proteins including type XVI collagen (21) can serve as substrates for Factor XIIIa, suggesting that Factor XIIIa plays a significant role in cell tensegrity and cellular functions characterized by intense cytoskeletal reorganization.

Cell tensegrity represents the influence of mechanical stress on the cell shape by modelling its cytoskeleton. Factor XIIIa ${ }^{+}$ DD exhibit striking changes in their appearance according to the intrinsic mechanical forces present in the skin $(27,29,34$, $35)$. They are rarefied and thin in the loose connective tissue of Ehlers-Danlos syndrome $(27,34)$, but appear plump in acromegaly (29). During tissue expansion in animals, the expression of Factor XIIIa appears to be completely abolished (36). 
Notably, methotrexate was found to severely alter DD tensegrity giving them a ballooned appearance (37). This effect is likely to be related to the direct influence of the drug on the cytoskeleton (38).

\section{Factor XIIIa ${ }^{+}$dendrocytes in dermatitides}

Factor XIII is of potential significance as a modulator of inflammation. Some arguments also refer to local consumption and/or loss of Factor XIII within the inflamed tissue during acute episodes of inflammatory bowel diseases. Generally, Factor XIIIa ${ }^{+}$cells in pathological skin conditions can be split into expression in inflammatory and fibrosing conditions, and in neoplastic pathology. Inflammatory macrophages may release or express Factor XIIIa at their surface. The important role ascribed to Factor XIII in inflammation is related to the fact that several adhesive glycoproteins are transglutaminase substrates. The enzyme may play an important role in cell adhesion and migration.

In terms of inflammation Factor XIIIa expression is elevated in several conditions including spongiotic dermatoses, lichen planus and psoriasis $(1,5,11,13,39-43)$. In acute and chronic graft-versus-host disease (GVHD), expression of Factor XIIIa in DD is altered and usually increased $(16,19,25,42,44,45)$. Migration of Factor XIIIa ${ }^{+}$cells into the epidermal compartment has been reported in chronic plaque psoriasis in association with other inflammatory cells (13). Chronic sun exposure and PUVA therapy are responsible for the same phenomenon $(46,47)$. This feature is not limited to a few inflammatory diseases as it is commonly found in mycosis fungoides (48).

Toxic epidermal necrolysis (Lyell syndrome) is another example in which Factor XIIIa+ DD are numerous (19,49-52). In this syndrome, a contrasting feature is present in lymph nodes where the Factor XIIIa ${ }^{+}$cells are rarefied (53).

It has been postulated that DD significantly influence lymphocyte migration in the skin through TNF- $\alpha$ production (49-51). This cytokine induces the keratinocyte production of interleukin-8 ( $\mathrm{T}$ cell and neutrophil chemoattractant) and ICAM expression ( $\mathrm{T}$ cell-keratinocyte communication signal). Thus, this mechanism appears to be an important aspect of DD function (54).

In leukocytoclastic vasculitis, Factor XIIIa-positive DD abutted to the involved microvasculature are altered giving rise to the features of dendrocytoclasia (54). In contrast, numerous normal-looking Factor XIIIa ${ }^{+}$DD accumulate in chronic erythema elevatum diutinum (43).

Some drugs appear to increase the size and number of Factor $\mathrm{XIIIa}^{+} \mathrm{DD}$. Among them, etretinate, retinoic acid and imiquimod show activity on DD in the papillary dermis (56-59). Imiquimod appears to be markedly ineffective against tumoral lesions lacking a regular amount of Factor XIIIa+ DD $(60,61)$. This suggests that these cells participate in the druginduced release of the cytokine storm-inducing tumoral regression. Cyclosporin is another drug which can alter the presentation of Factor XIIIa ${ }^{+}$DD (62).

\section{Factor XIIIa ${ }^{+}$dendrocytes in phagocytic disorders}

One of the intracellular functions of Factor XIIIa may be related to receptor-mediated phagocytosis. Macrophages bind a2-macroglobulin protease complexes which are known to be a substrate for plasma Factor XIII (63). There is evidence showing that ligand-receptor binding and the internalization of $\alpha 2$-macroglobulin complexes require transglutaminase activity. Increasing phagocyte activity is strongly associated with the expression of Factor XIIIa (63). Monocytes from Factor XIIIa-deficient patients show an impaired capacity to phagocytosis, while their locomotion remains normal. Among the steps of the phagocytic pathway, the mechanism of internalization of particles is most affected by the lack of Factor XIIIa (64).

Two further observations are suggestive of the Factor XIIIa involvement mechanism of phagocytosis. Peritoneal macrophages show condensation of Factor XIIIa in the pseudopodia and around phagocytotic vesicles. However, human myelomonocytic cell lines, which are incapable of phagocytosis do not express Factor XIIIa. During their differentiation induced by phorbolester, these cells demonstrate increased phagocytosis in parallel with the expression of Factor XIIIa. Ultrastructural studies have also demonstrated DD activation with enlarged endoplasmic reticulum and collagen fiber and mast cell granular phagocytosis in pathological conditions (31). These include toxic epidermal necrolysis and graft-versushost reaction (19). In dermal melanoderma, melanophages express Factor XIIIa $(15,32)$.

Diverse tumoral conditions accumulate cells of this lineage which show variable levels of the activation of phagocytosis. Xanthogranulomas (64), nodular histiocytosis (65) and reticulohistiocytomas $(66,67)$ are typical examples.

\section{Factor XIIIa ${ }^{+}$dendrocytes in fibroplasia}

Factor XIIIa has a diagnostic value in certain fibrosing disorders. DD play a central role in the pathogenesis of some disorders associated with focal connective tissue hyperplasia. They represent the predominant cell type in dermatofibroma, dendrocytoma, histiocytoma, angiohistiocytoma and epithelioid cell histiocytoma (68-77). However, there is an array of patterns that ranges from sporadic to diffuse expression of Factor XIIIa. An immunoelectronmicroscopic examination of Factor XIIIa+ DD in dermatofibromas reveals that these cells display moderate to abundant rough endoplasmic reticulum, lipid droplets and/or bundles or myofilaments in varying proportions. There is also evidence of macular adherence connections between neighbouring cells. Most likely, the variability in Factor XIIIa expression in dermato-fibroma is the result of the age of the lesion. Similarly, this appears to be true in morphoea $(78,79)$. Variability of expression suggests that the Factor XIIIa expression in dermal cells is a facultative function induced by undefined factors that are released locally (80). It is possible that the transforming growth factor (TGF)- $\beta 1$ is released by Factor XIIIa ${ }^{+}$DD (81). A vicious cycle ensues as TGF- $\beta 1$ regulates dendritic cell maturation leading to further recruitment and activation of DD and more TGF- $\beta 1$ production resulting in tissue fibroplasia.

A similar mechanism is probably operative in disorders such as scleromyxoedema and nephrogenic systemic fibrosis (82). In early lesions, a marked thickening of the dermis is accompanied by the accumulation of cells with long dendritic processes. In fully developed cases, they are often associated 
with histiocytes and stellate Factor XIIIa+ DD. In addition, CD34+ DD with the dendritic processes form a dense network. It has been suggested that the CD34+ cells are circulating cells that have been recruited to the dermis. There is also an increased number of $\mathrm{CD}^{2} 8^{+}$and Factor $\mathrm{XIII}^{+} \mathrm{DD}$, some of which are positive for the two markers (83-87).

Factor XIIIa+ DD may be almost absent in sclerotic areas associated with benign and malignant neoplasms $(70,78,88)$. The connective tissue built up in epulis show changes at different stages and Factor XIII is detected in monocytederived tissue macrophages, which are widely and homogeneously distributed in granulation tissue. During the fibrotic process, tumor-associated macrophages (TAMs) corresponding to Factor XIIIa ${ }^{+}$cells continuously decline in number. They are only recognized at the periphery of fibrosing foci and their morphological appearance alters from a stellate to spindle shape (89). In other conditions including collagenomas, the solitary fibrous tumor of the skin and dermatofibrosarcoma protuberans, Factor XIIIa+ DD are reduced or absent $(72,88-91)$. Hence, these cells probably play a role in the regulation of fibrosing processes $(18,78)$.

An altered cytokine expression probably increases Factor XIIIa expression, particularly in T cell-mediated mycosis fungoides $(48,92)$. Its absence in other cutaneous lymphomas corresponds with aggravation of the disease.

\section{Factor $\mathrm{XIIIa}^{+}$dendrocytes in wound healing}

Factor XIII may be a critical transglutaminase in connective tissue homeostasis and the repair process (93-97). Impaired wound healing observed in patients with homozygous Factor XIII deficiency suggests that the normal mechanism of wound healing and tissue repair requires this compound. Factor XIIIa not only stimulates fibroblast proliferation in vitro but is also a significant regulator of collagen biosynthesis by these cells $(98,99)$. Fibroblasts then produce growth factors, collagen, elastin and other extracellular matrix components important in matrix remodelling and repair.

Factor XIIIa+ DD have been shown to be related functionally and spatially to mast cells. They increase in number following mast cell degranulation. This has been linked to the release of TNF- $\alpha$, a predominant pre-formed cytokine in human mast cell granules (17). Keratinocytes and DD are other sources of TNF- $\alpha$ in the skin (100). Thus, exogenous threats that directly impact the skin (such as trauma), endogenous stimuli delivered to the skin from the blood stream (e.g. drug metabolites and immune complexes) or pathological events that can trigger TNF- $\alpha$ producing cells may stimulate Factor XIIIa expression by DD. In this way, DD may induce the proliferation of their own population by autocrine and paracrine pathways.

\section{Factor XIIIa ${ }^{+}$dendrocytes in neoplasms}

Factor XIIIa ${ }^{+}$DD are found in fibrovascular lesions including fibrous papules of the nose, acquired digital fibrokeratomas, angiofibromas and oral fibromas $(80,98,101-106)$. Factor XIIIa is possibly acting as a growth factor in these tumors, or these neoplasms are releasing an undefined stimulus. This is also the case in desmoplastic neoplasms (107). Increased numbers of Factor XIIIa ${ }^{+}$cells are often found at the base or surrounding most invasive cutaneous neoplasms (108-110). Such cells are often negative for conventional macrophage markers such as CD68. In our experience, Factor XIIIa ${ }^{+}$DD are numerous, abutting on and infiltrating most basal cell carcinomas and thin malignant melanomas (108). In contrast, they were present in only low numbers or even absent in thick primary malignant melanomas and their metastases (109-111). Circumstantial evidence linked the density of Factor XIIIa ${ }^{+}$dendritic cells and a low proliferative rate of neoplastic cells in malignant melanoma. Thus, Factor XIIIa ${ }^{+}$ DD may not be passive in this neoplasm. Their function may differ based on whether they are located in the stroma or inside the neoplasm. Intratumoral DD may exert a growthrestricting role. In contrast, stromal DD may be involved in the invasiveness and metastatic spread of the cutaneous malignancies.

The expression of Factor XIIIa in spindle-shaped cells in Kaposi disease may be of significance. Kaposi disease is an Herpes VIII-induced multifocal neoplasm involving various organs. It is possible that a DD presence is important to the angioproliferative response in this particular condition $(103,104,112)$.

Malignant fibrous histiocytomas and atypical fibrohistiocytomas exhibit Factor XIIIa expression in cells to a variable degree. It was assumed that since the neoplasms exhibit a wide spectrum of histological appearances, all of which are a variation of spindled fibroblast-like, undifferentiated and histiocytic or histocyte-like cells. Therefore, the Factor XIIIa ${ }^{+}$ cells represent different levels of fibrohistiocytic differentiation $(113,114)$.

Factor XIIIa is widely expressed in several tumor types belonging the series of non-Langerhans cell histiocytoses, such as xanthoma disseminatum and xanthogranulomas (115-117).

Among neural neoplasms, neurofibromas are enriched in Factor XIIIa+ DD $(118,119)$. Factor XIIIa has been reported to be positive in cellular neurothekeomas (120-122), a relatively rare benign cutaneous neoplasia frequently occurring in young adults on the head and neck. Factor $\mathrm{XIIIa}^{+}$cells have also been reported in granular cell tumors of the skin (123). Most of these neoplasms are derived from Schwann cells. The presence of Factor XIIIa ${ }^{+}$cells in granular cell tumors of the skin suggests that these tumors are an exception in the group of Schwannomas. The acral myxoinflammatory fibroblastic sarcoma normally reveals Factor XIIIa immunoreactivity (124).

Extravascular fibrin deposition is frequently observed within and around neoplastic tissue and has been implicated in various aspects of tumor growth. In areas of fibrin deposition, TAMs may release or express Factor XIII at their surface. This relationship strongly suggests that Factor XIIIa secreted by intact cells or released from damaged TAMs is involved in the stabilization of intratumoral fibrin network, which facilitates the tumor-matrix generation and tumor angiogenesis. Factor XIIIa ${ }^{+}$monocyte-derived TAMs prevail over all other cell types at the site of intratumoral fibrin formation in different malignant tumors and are strongly attached to the fibrin strands. Factor XIII expressed on the surface of TAMs or released from damaged cells may have a significant role in 
fibrin stabilization and in this way has an effect on tumor progression.

\section{Conclusion}

The precise role of DD in the skin remains to be elucidated in different reactive or tumoral conditions. These cells may be increased or modified, and non-immunocompetent cells may also express intracellular Factor XIIIa in response to an altered cytokine network. In these abnormal conditions, Factor XIIIa ${ }^{+}$cells in the dermis belong to largely heterogeneous populations. The cytokine TNF- $\alpha$ appears to play a prominent role in Factor XIIIa expression by dermal cells. The function of DD may be mainly related to the phagocytic pathway, and to connective tissue homeostasis. This means that Factor XIIIa ${ }^{+}$cells may have different stages of maturation/activation with a transitional state of differentiation. Factor $\mathrm{XIII}^{+}$cells may represent multiple cell types with a common expression of a ubiquitous enzyme with some of the Factor XIIIa ${ }^{+}$cells being antigen-presenting and others non-inflammatory. Thus, there are phenotypic and functional (80) subsets of Factor XIIIa ${ }^{+}$dermal cells. For example, they express either CD1a or CD14 or have a variable expression of HLADR (101). It is possible that Factor XIIIa is a marker expressed only at certain phases of development of the cells of Langerhans lineage, perhaps in relation to cytokines predominant in the dermis as opposed to the epidermal microenvironment (102).

\section{References}

1. Arrese Estrada J and Piérard GE: Factor XIIIa-positive dendrocytes and the dermal microvascular unit. Dermatologica 180: 51-53, 1990.

2. Robert C, Fuhlbrigge RC, Kieffer JD, Ayehumic S, Hune RO, Cheng G, Grabbe S, von Adrian UH and Kupper TS: Interaction of dendritic cells with skin endothelium: a new perspective in immunosurveillance. J Exp Med 19: 627-635, 1999.

3. Piérard-Franchimont C, Fazaa B, Benzarti H, Kort R, Arrese JE, Nikkels AF, Kamoun MR and Piérard GE: Phenotypic heterogeneity in the fibroblast-like cells of the dermis. Giorn Int Dermatol Ped 6: 7-13, 1994.

4. Zaba LC, Fuentes-Duculan J, Steinman RM, Krueger JG and Lowes MA: Normal human dermis contains distinct populations of CD11 $\mathrm{c}^{+} \mathrm{BDCA}-1^{+}$dendritic cells and CD163+ ${ }^{+} \mathrm{FXIIIa}^{+}$macrophages. J Clin Invest 117: 2117-2525, 2007.

5. Talme T, Schultzberg M, Sundqvist KG and Marcusson JA: Somatostatin and Factor XIIIa immunoreactive cells in psoriasis during clobetasol propionate and calcipotriol treatment. Acta Derm Venereol 79: 44-48, 1999.

6. Quatresooz P and Piérard GE: Immunohistochemical clues at ageing of the skin microvascular unit. J Cutan Pathol Epub June 17,2008

7. Muszbek I, Adany R and Mikkola H: Novel aspect of blood coagulation factor XIII. Structure, distribution, activation, and function. Crit Rev Clin Lab Sci 33: 357-421, 1996.

8. Wozniak G and Noll T: Factor XIII and wound healing. Haemostaseologie 22: 59-62, 2002.

9. Tosetto A, Castaman G and Rodeghiero F: Acquired plasma factor XIII deficiencies. Haematologica 78: S5-S10, 1993.

10. Inbal A and Dardik R: Role of coagulation factor XIII (FXIII) in angiogenesis and tissue repair. Pathophysiol Haemost Thromb 35: 162-165, 2006.

11. Cerio R, Griffiths CE, Cooper KD, et al: Characterization of factor XIIIa positive dermal dendritic cells in normal and inflamed skin. Br J Dermatol 121: 421-431, 1989.

12. Headington JT and Cerio R: Dendritic cells and the dermis. Am J Dermatopathol 12: 217-220, 1990.

13. Derrick EK, Barker JN, Khan A, et al: The tissue distribution of factor XIIIa positive cells. Histopathology 22: 157-162, 1993.
14. Cerio R, Spaull J, Oliver GF, et al: A study of factor XIIIa and MAC 387 immunolabeling in normal and pathological skin. Am J Dermatopathol 12: 221-233, 1990.

15. Hermanns-Lê T, Gerardy-Goffin F, Giet-Lesuisse M and Piérard GE: Ultrastructural study of melanoderma due to azidothymidine. Ann Pathol 13: 328-331, 1993.

16. Pimpinelli N, Romagnoli P, Bosi A, Santucci P, Mori M, Guidi S and Giannotti B: Dendritic cells in the skin after allogeneic bone marrow transplantation: immunohistochemical and electron microscopic monitoring. Eur J Dermatol 3: 310-317, 1993.

17. Sueki H, Whitaker D, Buchsbaum M and Murphy GF: Interactions between dermal dendrocytes and mast cells in human skin. Implications for hemostasis and matrix repair. Lab Invest 69: 160-172, 1993.

18. Moretto JC, Soslow R and Smoller BR: Atypical cells in radiation dermatitis express Factor XIIIa. Am J Dermatopathol 20: 370-372, 1998.

19. Hermanns-Lê T, Paquet P, Piérard-Franchimont C, Arrese JE and Piérard GE: Regulatory function of factor XIIIa-positive dendrocytes in incipient toxic epidermal necrolysis and graftversus-host reaction. A hypothesis. Dermatology 198: 184-186, 1999.

20. Yamazaki K: An ultrastructural and immunohistochemical study of elastofibroma: CD34, MEF-2, prominin 2 (CD133), and factor XIIIa-positive proliferating fibroblastic stromal cells connected by Cx43-type gap junctions. Ultrastruct Pathol 31: 209-219, 2007.

21. Akagi A, Tajima S, Ishibashi A, Matsubara Y, Takehana M, Kobayashi S and Yamaguchi N: Type XVI collagen is expressed in Factor XIIIa+ monocyte-derived dermal dendrocytes and constitutes a potential substrate for Factor XIIIa. J Invest Dermatol 118: 267-274, 2002.

22. Piérard-Franchimont C, Piérard GE, Hermanns-Lê T, Estrada JA, Verloes A and Mulliez N: Dermatopathological aspects of restrictive dermopathy. J Pathol 167: 223-228, 1992.

23. Trimble CL, Gray MH and McNutt NS: The distribution of Factor XIIIa-positive cells in the human fetus and placenta. Virch Arch A Pathol Anat 420: 513-518, 1992.

24. Meunier L, Gonzalez-Ramos A and Cooper KD: Heterogeneous populations of class II $\mathrm{MHC}^{+}$cells in human dermal cell suspensions. Identification of a small subset responsible for potent dermal antigen-presenting cell activity with features analogous to Langerhans cells. J Immunol 151: 4067-4080, 1993.

25. Piérard GE, Tassoudji N, Arrese J, Nikkels A, Hermanns-Lê T and Piérard-Franchimont C: L1-protein in incipient lymphocytedepleted graft-versus-host disease. Expression in keratinocytes and coexpression with factor XIIIa in dermal cells. Turk $\mathbf{J}$ Dermatopathol 7: 10-13, 1998.

26. Monteiro MR, Murphy EE, Galaria NA, Whitaker-Menezes D and Murphy GE: Cytological alterations in dermal dendrocytes in vitro: evidence for transformation to a non-dendritic phenotype. Br J Dermatol 143: 84-90, 2000.

27. Flagothier C, Goffin V, Hermanns-Lê T, Piérard GE and Quatresooz P: A four-generation Ehlers-Danlos syndrome with vascular dissections. Skin ultrastructure and biomechanical properties. J Med Eng Technol 31: 175-180, 2007.

28. Nestle FO, Zheng X, Thompson C, Turka L and Nickoloff BJ: Characterization of dermal dendritic cells obtained from normal human skin reveals phenotypic and functionally distinctive subsets. J Immunol 151: 6535-6545, 1993.

29. Quatresooz P, Hermanns-Lê T, Ciccarelli A, et al: Tensegrity and type I dermal dendrocytes in acromegaly. Eur J Clin Invest 35: 133-139, 2005.

30. Headington JT: The dermal dendrocyte. In: Advances in Dermatology. Callen JP, Dahl MV, Golitz LE (eds). Year book Medical Publ, Chicago, pp159-171, 1986.

31. Altman DA, Fivenson DP and Lee MW: Minocycline hyperpigmentation as a model for in situ phagocytic activity of Factor XIII positive dermal dendrocytes. J Cutan Pathol 19: 340-345, 1992.

32. Unver N, Frevschmidt-Paul P, Hörster S, Wenck H, Stäb F, Blatt $\mathrm{T}$ and Elsässer HP: Alterations in the epidermal-dermal melanin axis and factor XIIIa melanophages in senile lentigo and ageing skin. Br J Dermatol 155: 119-128, 2006.

33. Torocsik D, Bardos H, Nagy L, et al: Identification of factor XIII-A as a marker of alternative macrophage activation. Cell Mol Life Sci 62: 2132-2139, 2005.

34. Hermanns-Lê T and Piérard GE: Factor XIIIa-positive dendrocyte rarefaction in Ehlers-Danlos syndrome, classic type. Am J Dermatopathol 23: 427-430, 2001. 
35. Hermanns-Lê T, Uhoda I, Piérard-Franchimont C, et al: Factor XIIIa-positive dermal dendrocytes and shear wave propagation in human skin. Eur J Clin Invest 32: 847-851, 2002.

36. Penneys NS, Rademaker B, Jackson IT and Fasching MC: Loss of factor XIIIa in pig skin during tissue expansion. J Dermatol Sci 2: 62-65, 1991

37. Quatresooz P and Piérard GE: Dermal dendrocyte ballooning. Am J Clin Dermatol 7: 391-392, 2006.

38. Chen KR and Carlson JA: Clinical approach to cutaneous vasculitis. Am J Clin Dermatol 9: 71-92, 2008.

39. Morganroth GS, Chan LS, Weinstein GD, Voorhees J and Cooper K: Proliferating cells in psoriatic dermis are composed primarily of T-cells, endothelial cells and Factor XIIIa ${ }^{+}$ perivascular dendritic cells. J Invest Dermatol 96: 333-340, 1991.

40. Van Neer F, Zememan V, Cerio R, Langtry J and Staughton RCD: The role of Factor XIIIa-positive dermal dendrocytes in HIV-1positive psoriatics. Br J Dermatol 128: 29-33, 1993.

41. Regezi JA, Daniels TE, Saeb F and Nickoloff BJ: Increased submucosal Factor XIIIa positive dendrocytes in oral lichen planus. J Oral Pathol Lab Med 13: 114, 1994.

42. Deguchi M, Aiba S, Ohtani H, Nagura $H$ and Tagami $H$ : Comparison of the distribution and numbers of antigenpresenting cells among T-lymphocyte-mediated dermatoses: $\mathrm{CD} \mathrm{a}^{+}$, factor XIIIa ${ }^{+}$, and $\mathrm{CD} 68^{+}$cells in eczematous dermatitis, psoriasis, lichen planus and graft-versus-host disease. Arch Dermatol Res 294: 297-302, 2002.

43. Wahl CE, Bouldin MB and Gibson LE: Erythema elevatum diutinum: clinical, histopathologic and immunohistochemical characteristics of six patients. Am J Dermatopathol 27: 397-400, 2005.

44. Yoo YH, Park BS, Whitaker-Menezes D, et al: Dermal dendrocytes participate in the cellular pathology of experimental acute graft-versus-host disease. J Cutan Pathol 25: 426-434, 1998.

45. Hermanns-Lê T, Paquet P, Nikkels AF, et al: Prolonged imiquimod treatment and graft-versus-host reaction: histological mimicry in the pattern of monocyte-macrophage-dendrocyte lineage skin infiltration. Dermatology 206: 361-365, 2003.

46. Piérard-Franchimont C, Arrese Estrada J, Nikkels AF, et al: Dendrocytes et cellules dendritiques épidermiques au cours du photovieillissement. Ann Dermatol Venereol 117: 965-967, 1990.

47. Piérard GE, Nikkels AF, Arrese JE, et al: Dermal dendrocytes and photochemotherapy. Virchows Arch A 418: 311-314, 1991.

48. Piérard GE, Piérard-Franchimont C, Hermanns-Lê T, et al: Factor XIIIa-positive dendritic cells in mycosis fungoides. Cancer J 5: 226-229, 1992.

49. Paquet P, Nikkels A, Arrese JE, Vanderkelen A and Piérard GE: Macrophage and tumor necrosis factor-alpha in toxic epidermal necrolysis. Arch Dermatol 130: 605-608, 1994.

50. Paquet $P$ and Piérard GE: Erythema multiforme and toxic epidermal necrolysis. A comparative study. Am J Dermatopathol 19: 127-132, 1997.

51. Paquet P, Paquet F, Al Saleh W, Reper P, Vanderkelen A and Piérard GE: Immunoregulatory effector cells in drug-induced toxic epidermal necrolysis. Am J Dermatopathol 22: 413-417, 2000.

52. Paquet P, Jacob E, Damas P, Pirson J and Piérard G: Analytical quantification of the inflammatory cell infiltrate and CD95R expression during treatment of drug-induced toxic epidermal necrolysis. Arch Dermatol Res 297: 266-273, 2005.

53. Paquet P, Quatresooz P and Piérard GE: Factor XIIIa-positive dendrocytes in drug-induced toxic epidermal necrolysis (Lyell's syndrome). Paradoxical activation in the skin and rarefaction in lymph nodes. Dermatology 206: 374-378, 2003.

54. Paquet P, Ribbens $C$ and Piérard GE: Epidermal interleukin-8 and its receptor CXCR2 in drug-induced toxic epidermal necrolysis. Clin Exp Dermatol 32: 728-732, 2007.

55. Arrese Estrada J, Goffin F, Cornil F, et al: Dendrocytoclasis in Henoch-Schonlein purpura. Acta Derm Venereol 71: 358-359, 1991.

56. Hermanns-Lê T, Arrese Estrada J, Benr Mosbah T, et al: Modulating effect of etretinate on dendrocytes and dermal structure. Afr J Dermatol 3: 21-27, 1990.

57. Piérard GE, Kligman AM, Stoudemayer T, et al: Comparative effects of retinoic acid, glycolic acid and a lipophilic derivative of salicylic acid on photodamaged epidermis. Dermatology 199: 50-53, 1999.

58. Smith KJ, Hamza S and Skelton H: Topical imidazoquinoline therapy of cutaneous squamous cell carcinoma polarizes lymphoid and monocyte/macrophage populations to a Th1 and M1 cytokine pattern. Clin Exp Dermatol 29: 505-512, 2004.
59. Smith K, Hamza S, Germain M and Skelton H: Does imiquimod histologically rejuvenate ultraviolet radiation-damaged skin? Dermatol Surg 33: 1419-1428, 2007.

60. Arrese JE, Paquet P, Claessens N, et al: Dermal dendritic cells in anogenital warty lesions unresponsive to an immune-response modifier. J Cutan Pathol 28: 131-134, 2001.

61. Quatresooz P and Piérard GE: Imiquimod-responsive basal cell carcinomas and factor XIIIa-enriched dendrocytes. Clin Exp Dermatol 28: S27-S29, 2003.

62. Lago E, Carneiro S, Cuzzi T, Magalhaes G, Cassia F, Pessanha F and Ramos-e-Silva M: Clinical and immunohistochemical assessment of the effect of cyclosporin in keratinocytes and dermal dendrocytes in psoriasis. J Cutan Pathol 34: 15-21, 2007.

63. Andreopoulos A, Yiakoumis X, Antoniou TC, Andreopoulos G, Konstantopoulos K, Pangalis GA and Vaiopoulos G: Primary adult-onset macrophage activation syndrome with multisystemic tissue phagocytosis. Int J Hematol 86: 394-396, 2007.

64. Kraus MD, Haley JC, Ruiz R, Essary L, Moran CA and Fletcher CD: 'Juvenile' xanthogranuloma: an immunophenotypic study with a reappraisal of histogenesis. Am J Dermatopathol 23: 104-111, 2001.

65. Gonzalez Ruiz A, Bernal Ruiz AI, Aragoneses Fraile H, Peral Martinez I and Garcia Munoz M: Progressive nodular histiocytosis accompanied by systemic disorders. Br J Dermatol 143: 628-631, 2000

66. Luz FB, Gaspar AP, Ramos-e-Silva M, Carvalho da Fonseca E, Villar EG, Cordovil Pires AR and Kalil-Gaspar N: Immunohistochemical profile of multicentric reticulohistiocytosis. Skinmed 4: 71-77, 2005.

67. Miettinen $\mathrm{M}$ and Fetsch JF: Reticulohistiocytoma (solitary epithelioid histiocytoma): a clinicopathologic and immunohistochemical study of 44 cases. Am J Surg Pathol 30: 521-528, 2006.

68. Jones EW, Cerio R and Smith NP: Epithelioid cell histiocytoma: a new entity. Br J Dermatol 120: 185-195, 1989.

69. Cerio R, Spaull J and Jones EW: Histiocytoma cutis: a tumour of dermal dendrocytes (dermal dendrocytoma). Br J Dermatol 120: $197-206,1989$

70. Altman DA and Nickoloff BJ: Differential expression of Factor XIIIa and CD34 in cutaneous mesenchymal tumors. J Cutan Pathol 20: 154-158, 1993.

71. Dezfoulian B, Nikkels AF, Piérard-Franchimont C, et al: Epithelioid cell histocytoma: a report of two cases. Dermatology 190: 349-350, 1995

72. Zelger BW, Offren D and Zelger BG: Atrophic variants of dermatofibroma and dermatofibrosarcoma protuberans. Histopathology 26: 519-527, 1995

73. Goldblum JR and Tuthill RJ: CD34 and factor-XIIIa immunoreactivity in dermatofibrosarcoma protuberans and dermatofibroma. Am J Dermatopathol 19: 147-153, 1997.

74. Rodriguez-Jurado R, Palacios C, Duran-McKinster C, Mercadillo P, Orozco-Covarrubias L, Saez-de-Ocariz Mdel M and Ruiz-Maldonado R: Medallion-like dermal dendrocyte hamartoma: a new clinically and histopathologically distinct lesion. J Am Acad Dermatol 51: 359-363, 2004.

75. Song Y, Sakamoto F and Ito M: Characterization of factor $\mathrm{XIII}^{+}$dendritic cells in dermatofibroma: Immunohistochemical, electron and immunoelectron microscopical observations. J Dermatol Sci 39: 89-96, 2005.

76. Pérez LP, Zulaica A, Rodriguez L, Campo MC, Penaranda JM, Fernandez-Redondo V and Toribio J: Multinucleate cell angiohistiocytoma. Report of five cases. J Cutan Pahtol 33: 349-352, 2006.

77. Lee J: Epithelioid cell histiocytoma with granular cells (another nonneural granular cell neoplasm). Am J Dermatopathol 29: 475-476, 2007.

78. Piérard GE, Arrese Estrada J, Piérard-Franchimont C, et al: Is there a link between dendrocytes, fibrosis and sclerosis? Dermatologica 181: 264-265, 1990.

79. Gilmour TK, Wilkinson B, Breit SN and Kossard S: Analysis of dendritic cell populations using a revised histological staging of morphoea. Br J Dermatol 143: 183-192, 2000.

80. Penneys NS, Smith KJ and Nemeth AJ: Factor XIIIa in the hamartomas of tuberous sclerosis. J Dermatol Sci 2: 50-53, 1991.

81. Mendoza FA, Artlett CM, Sandorfi N, Latinis K, Piera-Velazquez S and Jimenez SA: Description of 12 cases of nephrogenic fibrosing dermopathy and review of the literature. Semin Arthritis Rheum 35: 208-210, 2006.

82. Kucher C, Xu X, Pasha T and Elenitsas R: Histopathologic comparison of nephrogenic fibrosing dermopathy and scleromyxedema. J Cutan Pathol 32: 484-490, 2005. 
83. Cowper SE, Su LD, Bhawan J, Robin HS and LeBoit PE: Nephrogenic fibrosing dermopathy. Am J Dermatopathol 23: 383-393, 2001

84. Jimenez SA, Artlett CM, Sandorfi N, et al: Dialysis-associated systemic fibrosis (nephrogenic fibrosing dermopathy): study of inflammatory cells and transforming growth factor beta 1 expression in affected skin. Arthritis Rheum 50: 2660-2666, 2004.

85.Daram SR, Cortese CM and Bastani B: Nephrogenic fibrosing dermopathy/nephrogenic systemic fibrosis: report of a new case with literature review. Am J Kidney Dis 46: 754-759, 2005.

86.Parsons AC, Yosipovitch G, Sheehan DJ, et al: Transglutaminases: the missing link in nephrogenic systemic fibrosis. Am J Dermatopathol 29: 433-436, 2007.

87. Tsai CW, Chao CC, Wu VC, et al: Nephrogenic fibrosing dermopathy in a peritoneal dialysis patient. Kidney Int 72 : $1294,2007$.

88. Stewart MI and Smoller BR: Dermal dendrocytes are decreased in collagenomas. J Cutan Pathol 20: 504-507, 1993.

89. Adany R and Muszbek L: Cells containing factor XIII subunit a in benign and soft tissue tumors. Histopathology 11: 1341-1343, 1987.

90.Erdag G, Oureshi HS, Patterson JW, et al: Solitary fibrous tumors of the skin: a clinicopathologic study of 10 cases and review of the literature. J Cutan Pathol 34: 844-850, 2007.

91. Kim HJ, Lee JY, Kim SH, et al: Stromelysin-3 expression in the differential diagnosis of dermatofibroma and dermatofibrosarcoma protuberans: comparison with factor XIIIa and CD34. Br J Dermatol 157: 319-324, 2007.

92. Fivenson DP, Beckers R, Dunstan RW and Nickoloff BJ: Dermal dendrocytes and $\mathrm{T}$ cells in canine mycosis fungoides: support for an animal model of human cutaneous cell lymphoma. Cancer 70: 2091, 1992.

93. Gilbran NS, Hembach DM and Holbrook KA: Immunolocalization of FXIIIa ${ }^{+}$dendritic cells in human burn wounds. J Surg Res 59: 378-386, 1995.

94. Griffin TD, Murphy GF, Sueki H, Telegan B, Johnson WC, Ditre CM, Yu RJ and Van Scott EJ: Increased factor XIIIa transglutaminase expression in dermal dendrocytes after treatment with $\alpha$-hydroxyacids: potential physiologic significance. J Am Acad Dermatol 34: 196-203, 1996

95. Fumal I, Braham C, Paquet P, Piérard-Franchimont C and Piérard GE: The beneficial toxicity paradox of antimicrobials in leg ulcer healing impaired by a polymicrobial flora: a proofof-concept study. Dermatology 204: S70-S74, 2002.

96. Quatresooz P, Henry F, Paquet P, Piérard-Franchimont C, Harding $\mathrm{K}$ and Piérard GE: Deciphering cytokine pathways in chronic leg ulcers. Int J Mol Med 11: 411-418, 2003.

97. Paquet P, Jacob E, Quatresooz P, Jacquemin D and Piérard GE: Delayed reepithelialization and scarring deregulation following drug-induced toxic epidermal necrolysis. Burns 33: 100-104, 2007.

98. Nemeth AJ, Penneys NS and Bernstein HB: Fibrous papule: a tumor of fibrohistiocytic cells that contain Factor XIIIa. J Am Acad Dermatol 19: 1102-1106, 1988

99. Greenberg CS, Birckbichler PJ and Rice RH: Transglutaminases: multifunctional cross-linking enzymes that stabilize tissues. FASEB J 5: 3071-3077, 1991.

100. Nickoloff BJ, Karabin GD, Barker JNW, Griffiths CEM, Sarma V, Mitras RS, Elder S, Kunkel SL and Dixit VM: Cellular localization of interleukin-8 audits inducer, tumor necrosisalpha in psoriasis. Am J Pathol 138: 129-140, 1991.

101. Nemeth AJ and Penneys NS: Factor XIII is expressed by fibroblasts in fibrovascular tumors. J Cutan Pathol 16: 266-271, 1989.

102. Nickoloff BJ and Griffiths CEM: Factor XIIIa-expressing dermal dendrocytes in AIDS-associated cutaneous Kaposi's sarcoma. Science 143: 1736-1737, 1989

103. Nickoloff BJ and Griffiths CE: The spindle-shaped cells in cutaneous Kaposi's sarcoma. Histologic simulators include factor XIIIa dermal dendrocytes. Am J Pathol 135: 793-800, 1989.
104. Gray MH, Trinble CC and Zurn J: Relationship of factor XIIIapositive dermal dendrocytes to Kaposi's sarcoma. Arch Pathol Lab Med 115: 791-796, 1991.

105. Arrese Estrada J and Piérard GE: Dendrocytes in verruga peruana and bacillary angiomatosis. Dermatology 184: 22-25, 1992

106. Regezi JA, Nickoloff BJ and Headington JT: Oral submucosa dendrocytes factor $\mathrm{XIII}^{+}$and $\mathrm{CD} 34^{+}$dendritic cell populations in normal tissue and fibrovascular lesions. J Cutan Pathol 19: 398-406, 1992.

107. Watanabe H, Ishida Y, Nagashima K, Makino T, Norisugi O and Shimizu T: Desmoplastic fibroblastoma (collagenous fibroma). J Dermatol 35: 93-97, 2008

108. Piérard-Franchimont C, Arrese JE, Nikkels AF, et al:. Factor XIIIa-positive dermal dendrocytes and proliferative activity of cutaneous cancers. Virchows Arch 429: 43-48, 1996.

109. Denton KJ, Cotton DW, Wright A and Hird P: Factor XIIIIa in nodular malignant melanoma and Spitz naevi. Br J Dermatol 12: $783-786,1990$

110.Fullen DR and Headington JT: Factor XIIIa-positive dermal dendritic cells and HLA-DR expression in radial versus vertical growth-phase melanomas. J Cutan Pathol 25: 553-558, 1998.

111.Polak ME, Johnson P, Di Palma S, Higgins B, Hurren J, Borthwick NJ, Jager MJ, McCormick D and Cree IA: Presence and maturity of dendritic cells in melanoma lymph node metastases. J Pathol 207: 83-90, 2005.

112. Kanitakis J and Roca-Miralles M: Factor XIIIa-expressing dermal dendrocytes in Kaposi's sarcoma. A comparison between classical and immunosuppression-associated types. Virchows Archiv A Pathol Anat 420: 217-231, 1992.

113. Nemes Z and Thomázy V: Factor XIIIa and the classic histiocytic markers in malignant fibrous histiocytoma: a comparative immunohistochemical study. Hum Pathol 19: 822-829, 1988.

114. Wilk M, Zelger BG, Nilles M and Zelger B: The value of immunohistochemistry in atypical cutaneous fibrous histiocytoma. Am J Dermatopathol 26: 367-371, 2004.

115.Zelger B, Cerio R, Orchard G, et al: Histologic and immunohistochemical study comparing xanthoma disseminatum and histiocytosis X. Arch Dermatol 128: 1207-1212, 1992.

116. Misery L, Boucheron S and Claudy AL: Factor XIIIa expression in juvenile xanthogranuloma. Acta Derma Venereol 74 (Suppl): S43-S44, 1994.

117.Zelger BG, Orchard G, Rudolph P, et al: Scalloped cell xanthogranuloma. Histopathology 32: 368-374, 1998.

118. Gray MH, Smoller BR, McNutt NS and Hsu A: Immunohistochemical demonstration of factor XIII a expression in neurofibromas: a practical means of differentiating these tumors from neurotized melanocytic nevi and schwannomas. Arch Dermatol 126: 472-476, 1990.

119. Takata M, Imai T and Hirone T: Factor XIII-positive cells in normal peripheral nerves and cutaneous neurofibroma of type I neurofibromatosis. Am J Dermatopathol 16: 37-43, 1994

120. Mahalingam M, Alter JN and Bhawan J: Multiple cellular neurothekeomas - a case report and review on the role of immunohistochemistry as a histologic adjunct. J Cutan Pathol 33: 51-56, 2006.

121. Alkhalidi H and Ghazarian D: Cellular neurothekeoma with a plexiform morphology: a case report with a discussion of the plexiform lesions of the skin. J Cutan Pathol 34: 264-269, 2007.

122.Wu RC, Hsieh YY, Chang YC and Kuo TT: Cellular neurothekeoma with melanocytosis. J Cutan Pathol 35: 241245,2008

123. Nikkels AF, Arrese Estrada J, Piérard-Franchimont C, et al: CD68 and factor XIIIa expressions in granular-cell tumor of the skin. Dermatology 186: 106-108, 1993

124. Hassanein AM, Atkinson SP, Al-Ouran SZ, Jain SM and Reith JD Acral myxoinflammatory fibroblastic sarcomas: are they all low-grade neoplasms? J Cutan Pathol 35: 186-191, 2008. 